\title{
Caterpillar Sales Conference
}

Bob Hewitt of Hewitt Equipment Limited, Montreal, attended a two-day sales conference for dealers of Caterpillar equipment during the second week of December. The conference, which took place in Arizona, was held for the purpose of introducing two new equipment lines to the dealers: the Caterpillar D8 Series $H$ Tractor and the No. 583 Series H Pipelayer. A general review of merchandising plans and a review of the business outlook was also undertaken.

\section{EMPLOYMENT}

For your convenience the Forestry Chronicle offers a free employment service. Prospective employers or applicants should write to Mr. George A. Sinclair, Forest Ranger School, Dorset, Ontario, who will prepare applications for publication. Applicants are requested to include their own advertisement giving the following information: University granting degree, year of graduation, years and type of experience and type of employment preferred.

The Government of Newfoundland invites applications for two positions of Regional Foresters in the Forestry Division of the Department of Mines and Resources.

Preference will be given to graduate foresters with at least three years practical experience having a particular interest in forest management.

Successful applicants will be required to supply medical certificate, abide by the rules of the Civil Service and reside in Newfoundland at Lewisporte or Corner Brook.

Salary will be on the scale of $\$ 4290-\$ 4620$ with an annual increment of $\$ 100.00$.

Application in writing giving full particulars of qualifications together with references may be submitted to P. J. Murray, Deputy Minister of Resources, St. John's, Newfoundland.

Employment Wanted: Forestry Graduate, U.N.B. 1954, married, one child, 4 years continuous field and office work in forest inventories, presently in charge of forestry department of lumber company, desires similar work in organization with greater opportunities for advancement. Please refer to code No. F.I. 2.

Employment Wanted: Forestry Graduate, Goettingen University, 1951, 36 years of age, married with four children, experienced in bush operation including logging, management, silviculture research, reforestation with particular reference to poplar hybrids, and production of plywood and veneer, desires a position requiring responsibility, initiative and an opportunity to do analysis and appraisal work. Please refer to code No. F.M. 3. 